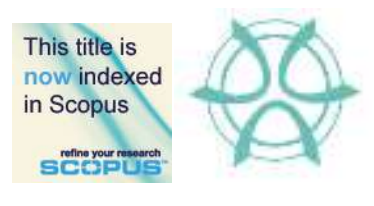

PLANNING MALAYSIA:

Journal of the Malaysian Institute of Planners

VOLUME 18 ISSUE 4 (2020), Page 352 - 364

\title{
DAM RELATED DISASTER FRAMEWORK FOR EMERGENCY PREPAREDNESS
}

\author{
Rahsidi Sabri Muda ${ }^{1}$, Izawati Tukiman', Mohamad Faiq Md Amin ${ }^{3}$, \\ Mohd. Ramzi Bin Mohd. Hussain ${ }^{4}$, Ainul Bahiah Mohd Khidzir ${ }^{5}$ \\ ${ }_{1,3,4}$ Civil Engineering and Geoinformatics \\ TNB RESEARCH SDN. BHD. MALAYSIA \\ ${ }^{2,4}$ Kulliyyah of Architecture and Environmental Design \\ INTERNATIONAL ISLAMIC UNIVERSITY MALAYSIA
}

\begin{abstract}
Continuous approach and solution in solving resilience over a few decades are yet to resolve the main issue in developing sustainable development, disaster risk reduction and new challenges on climate change. Current frameworks that have been developed tend to be over-generalized which required major changes in developing effective frameworks appropriate for specific disaster phenomena. To address this issue, a clear objective and approach are required to help the community, authorities and government to enhance preparedness and response in case of disaster. The main objective of this paper is to present the theory and analysis in the development of effective disaster risk reduction framework for dam related disaster (DRD). With the intention of strengthening societal capacity for resilience, this paper will introduce the framework for disaster preparedness to bridge readiness among community, agency and dam owners. The methodology employed to develop a framework based on ICBDM model conducted in the study area, utilising surveys questionnaire, FGD and hazard assessment. The framework established detailed flow of response throughout all phases including pre-event, during event and post event which include hazard assessment, community and authority planning, establishment of emergency and safe passage, and aims to minimize loss of life and injury. In practice, this framework poses as an interactive and cohesive community approach to face dam related disasters (DRD) which will enhance overall response in disaster risk reduction programs.
\end{abstract}

Keywords: Community preparedness, framework, dam related disaster

\footnotetext{
${ }^{1}$ Principal Researcher at TNB Research Sdn. Bhd. Email: rahsidism@tnb.com.my
} 
PLANNING MALAYSIA

Journal of the Malaysia Institute of Planners (2020)

\section{INTRODUCTION}

Disaster risk governance is important for effective and efficient management of disaster risk which covers many aspects, as well as the participation of relevant stakeholders are needed. Increasing disaster risk governance for prevention, mitigation, preparedness, response, recovery and rehabilitation is necessary through fostering collaboration and partnership across mechanisms and institutions for the implementation of instruments relevant to disaster risk reduction and sustainable development.

According to Niekerk (2007), disaster risk reduction (DRR) is a systematic development and application of policies, strategies and practices to minimize vulnerabilities and disaster risks throughout a society, by preventing and limiting the adverse impact of hazards, within the broad context of sustainable development (Niekerk, 2007). On the other hand, the disaster risk management (DRM) was defined by the United Nations International Strategy for Disaster Reduction (UNISDR) as:

"The systematic process of using administrative directives, organizations, and operational skills and capacities to implement strategies, policies and improved coping capacities in order to lessen the adverse impacts of hazards and the possibility of disaster." (UNISDR, 2009; UNISDR, 2018)

Mohammed (2018) defines disaster management as an ongoing process composed of a set of activities before, during, and after an event and it falls into four main stages which are preparation, response, recovery, and mitigation. Each stage involves the management and coordination of a wide range of stakeholders such as government agencies, non-government organizations, emergency response teams, and residents. The preparation phase is the earliest action in mitigating disaster. Preparedness activities such as siren for early warning are designed to plan the unthinkable and increase the readiness of organizations and communities to respond to a catastrophe timely and expertly. Mohammed (2018) also highlighted that training on disaster preparation and response are required such as search and rescue, and some operations to respond with basic or intermediate incident command.

As reported by United Nations (UN), Hyogo Framework (2005-2015) emphasized more on policies, which it does not able to capture the dynamics of hazards, exposure and vulnerability, due to the lack of accountability and multilevel disaster management governance system at the local, national and regional levels (Scolobig et al., 2015; Eltinay \& Charles, 2017; Tiernan et.el, 2019). Thus, in order to reduce the impact of a disaster to human life, a systematic approach has been taken through disaster risk management and disaster risk reduction at all level, Sendai Framework for Disaster Risk Reduction 2015-2030 
R.S. Muda, I. Tukiman, M.F.M. Amin, A.B. Khidzir

Disaster Risk Reduction Framework for Dam Related Disaster

(SFDRM2015-2030) was introduced in aims to achieve the substantial reduction of disaster risk and losses in lives, livelihoods and health and in the economic, physical, social, cultural and environmental assets of persons, businesses, communities and countries over the next 15 years (Tiernan et.el, 2019) The scope of the SFDRM is broader than the HFA, which covered disasters caused by natural and man-made hazards and related environmental, technological and biological (Oxley, 2013).

Many Scholars has suggests that continuous effort for disaster emergency frameworks need to be improved, especially on critical aspects such as accountability, vulnerability, exposure, dynamics of hazard and overall disaster management governance system at various levels (Scolobig et al., 2015; Eltinay \& Charles, 2017; Tiernan et.el, 2019). Since the 1980s, policies and processes have been developed for disaster risk reduction; the chronology of development is illustrated in Figure 1.

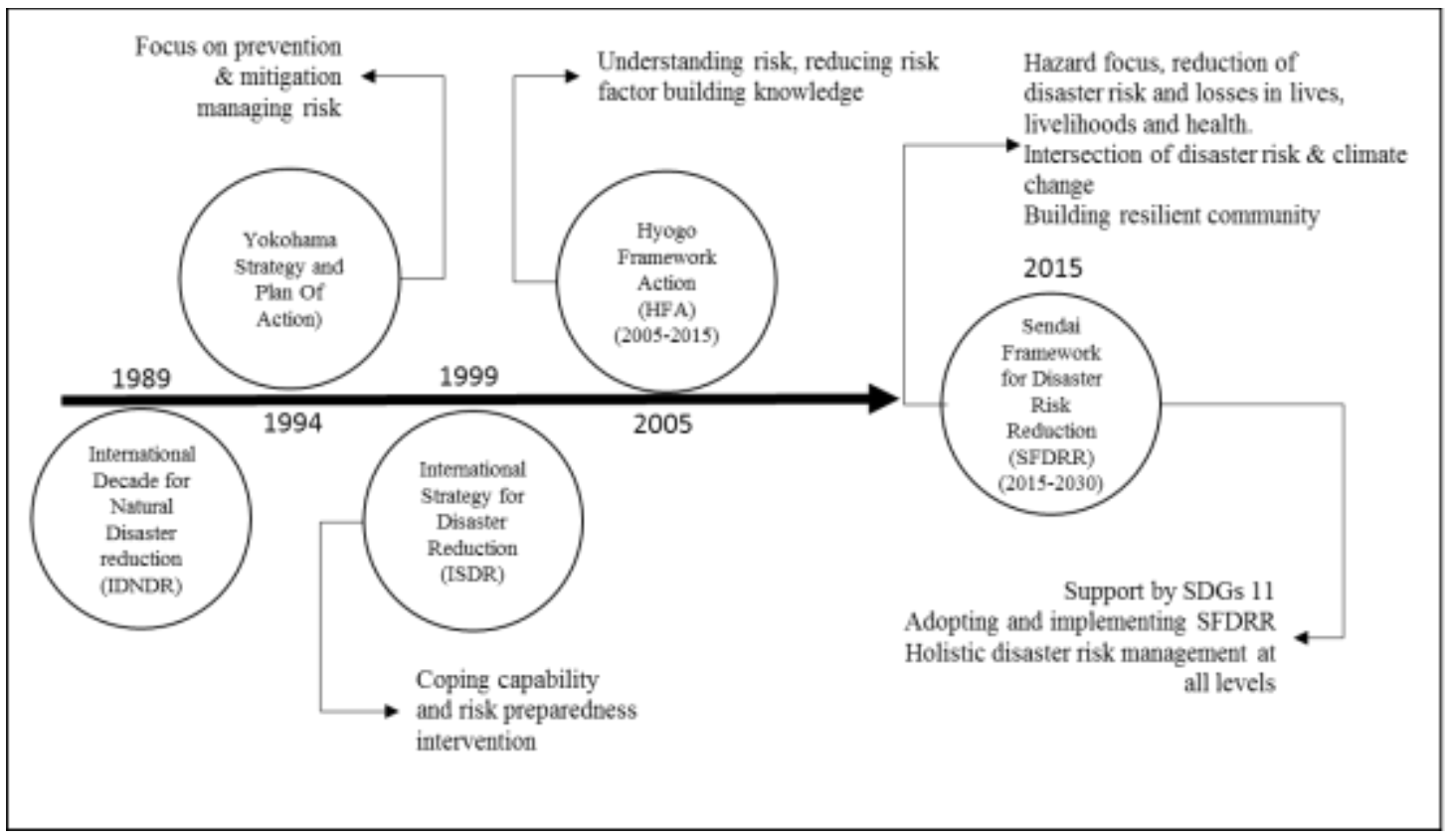

Figure 1: Evolution toward Sendai Framework Disaster Risk Reduction (SFDRR) (Adopted from Aitsi-selmi et al., 2015, Tiernan et al. (2019)

\section{DISASTER MANAGEMENT IN MALAYSIA}

In Malaysia, the National Security Council (NSC) governs disaster events through monitoring, directing and evaluating processes. Among disaster related guidelines developed under NSC is NSC Directive No. 20 (MKN20) which covers comprehensive guidelines in facing disaster at all levels for government 
agencies. NSC is responsible for appointing a task force, managing resources and leading the operation in any related disaster occurrences in Malaysia. The operations of NSC directives has been arranged with considerations of culture, ethics, behaviour at district and local community, and geographical condition which focuses on minimizing on the ground gaps in facing disaster (Maidin et al., 2017).

One of the important roles of NSC is to control Disaster Management and Relief Committee (DMRC) at all levels; district, state and national as shown in Figure 2 (Khalid \& Shafiai, 2015). NSC has the authority in formulating policies related to a disaster, assessment on potential risk areas, enhancing public education in facing disaster, training for selected agencies, providing resources and logistics support and preparing suitable machinery and tools. Apart from operational tasks, NSC developed a comprehensive database containing information about expertise and skills pool in agencies, equipment and tools as part of the disaster management program.

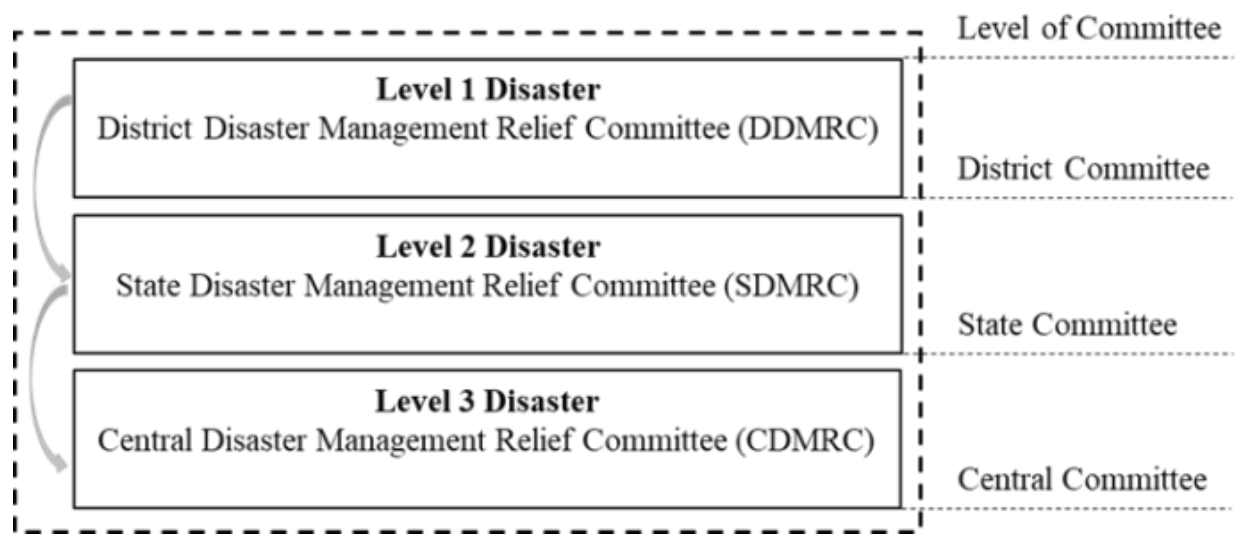

Figure 2: Adopted from Disaster Management Committees (MKN), Jabatan Perdana Menteri, 2012 (MKN, 2012)

\section{INSTITUTIONAL, LEGISLATIVE AND POLICY IN DISASTER MANAGEMENT}

Disaster Risk Management (DRM) and Disaster Risk Reduction (DRR) emerged as systematic approaches to reduce the impact of a disaster on human life. Throughout the years, the government is focusing on centered capacity and capability for disaster response and on disaster response and recovery. Recently the focus has shifted to disaster preparedness and management, by introducing the concept of disaster risk reduction in various sectors of the government (Izumi, T., Matsuura et al., 2019). Two important policies in disaster management have been established which are, Directive 19; the Special Malaysia Disaster 
R.S. Muda, I. Tukiman, M.F.M. Amin, A.B. Khidzir

Disaster Risk Reduction Framework for Dam Related Disaster

Assistance and Rescue Team in 1994 and in 1997 Directive 20; the groundwork for standard operating procedures and organizational framework for disaster response. Malaysia's national agency for crisis and disaster management was established in 2015, known as The National Disaster Management Agency (NADMA). NADMA is the focal point of national disaster management at the federal, state, and district levels. Figure 3 shows the evolution of disaster management in Malaysia.

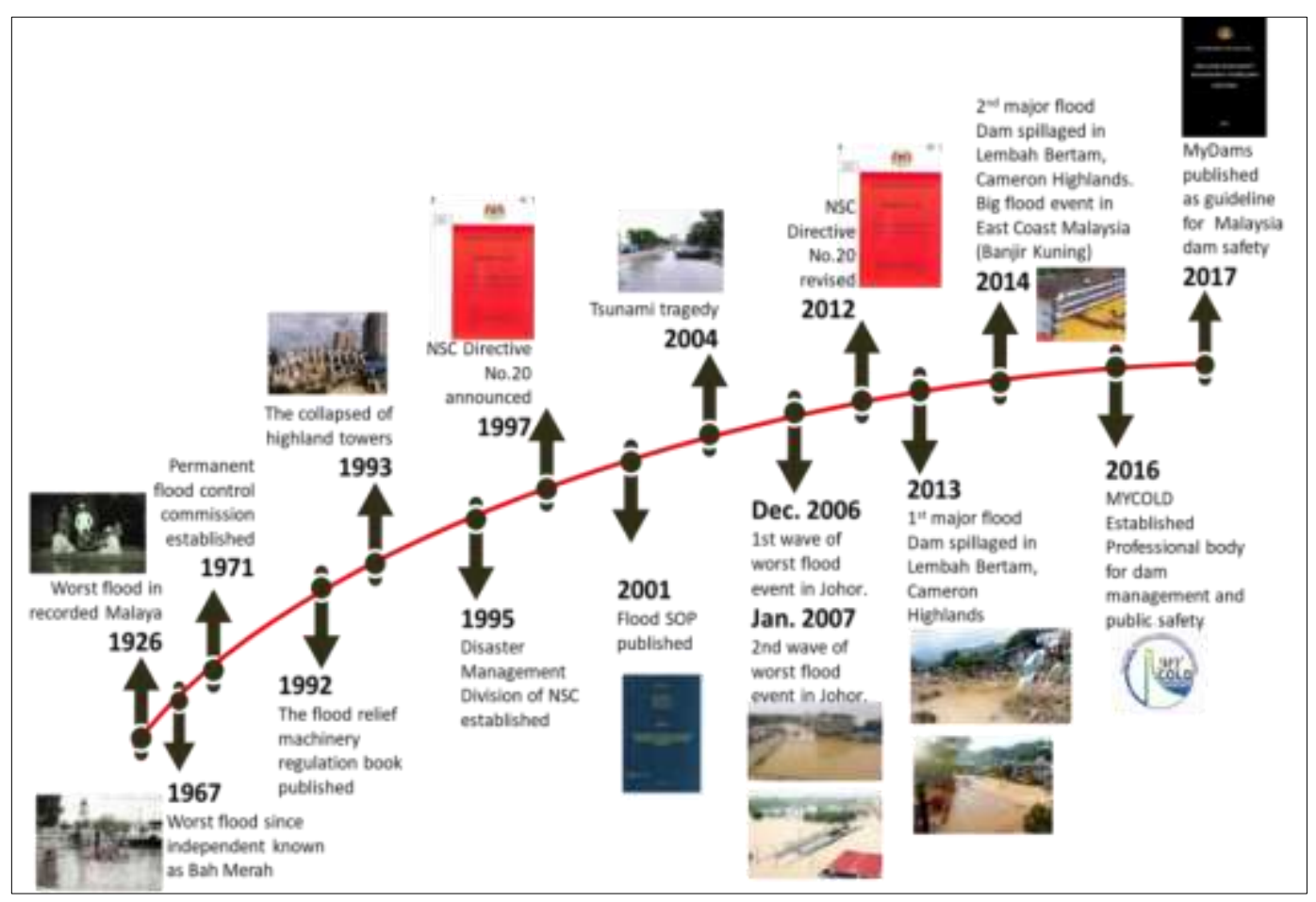

Figure 3: The evolution of disaster management in Malaysia. ( Adopted from Izumi, T., Matsuura et al., (2019)

\section{FRAMEWORK ON DISASTER RISK REDUCTION}

According to Marchezini et al. (2018), most efforts have been concentrated on developing systems, methodologies, and approaches rather than understanding people's requirements or ways of better engaging them in disaster risk reduction programs. Engaging local people is very important because they are the true first responders to mobilize during emergencies and they have a critical role in saving lives and in rendering assistance to those in need (Mickey Glantz \& Ramírez, 2018). It was agreed by Pal et al. (2017) mentioned that managing risk is more efficient and effective through sociotechnical systems that incorporate local 
people and local authorities. Other researchers also mentioned that framework for emergency preparedness should emphasize on the inter-organizational, and interjurisdictional process to increase people readiness to face disaster (Marchezini, Eduardo, et al., 2018; Pal et al., 2017; Quansah \& Engel, 2010).

Chang et al., (2016) and Tipler et al., (2017) suggest that preventive steps need to be taken earlier to avoid uncontrolled situations in managing disaster occurrences, unprepared communities have less ability to take control over the disaster event. This was supported by Patrisina et al., (2018) which mentioned that if an individual in the community is familiar and well prepared with ways of coping and precautionary measures, then the disruption by a disaster can be reduced. Furthermore, the implementation of policy and active involvement of local government in DRR enabled to mitigate the risk and potentially to increase preparedness among agencies and communities (Okada, 2012). This was obviously agreed by many researchers the need for a multistakeholders' involvement in line with global best practices aimed at reducing disaster risk (Shaw, 2013; Shaw, 2014)

\section{DESIGN OF METHODOLOGY}

An integration method of qualitative and quantitative have been applied to develop the proposed framework. Content analysis has been done in the early phase of the research to study the development of effective disaster risk reduction framework for dam related disaster (DRD) from other countries. Primary data were collected through community surveys questionnaire, focus group discussions (FGD) and expert interviews. A survey with 847 community at risk was conducted for obtaining quantitative data regarding community preparedness toward dam disaster in their vicinity area. Questionnaire survey and FGD was designed to gauge respond on respondents' knowledge, awareness and preparedness on facing disaster strike in Cameron Highland. A baseline study was conducted in Cameron Highlands to analyze the initial stage of ICBDM program. It provides basic demographic of the community, potential hazard, local knowledge, physical conditions and potential impact from dam related disaster (DRD). GIS mapping method is used to facilitate hazard assessment and vulnerable analysis, it uses overlay technique using ArcGIS application couple with flood model from secondary data.

The methodology designed is guided by the research questions, study objectives and disaster phases (Jamshed et al., 2018 and Ade Bilau et al., 2018). In developing emergency preparedness framework for DRD, ICBDM approach has been assessed and reviewed to get fully understanding of the overall process involved in the program. Emergency response plan (ERP), mode of notification, communication channel, chains of command system, early warning system and community and stakeholder's engagement program among the focal components 
R.S. Muda, I. Tukiman, M.F.M. Amin, A.B. Khidzir

Disaster Risk Reduction Framework for Dam Related Disaster

that have been assessed. An assessment approach in development framework as shows in Table 1.0.

Table 1: Methodology conducted to develop a framework for disaster

\begin{tabular}{|c|c|c|c|c|}
\hline Phase & Method & Assessment & Respondent & Research questions \\
\hline \multirow{4}{*}{ Pre-event } & GIS mapping method & $\begin{array}{c}\text { Risk and hazard } \\
\text { assessment }\end{array}$ & & \\
\hline & GIS mapping method & $\begin{array}{c}\text { Vulnerable } \\
\text { analysis }\end{array}$ & & \\
\hline & Questionnaire survey & $\begin{array}{l}\text { Awareness and } \\
\text { knowledge } \\
\text { EWS }\end{array}$ & Community & $\begin{array}{l}\text { To discover how far does the community } \\
\text { aware of the implication of dam-related } \\
\text { disaster }\end{array}$ \\
\hline & FGD & ERP & Authorities & $\begin{array}{l}\text { - What is the SOP during an emergency? } \\
\text { - How was the safety measure conducted at } \\
\text { the agency level? }\end{array}$ \\
\hline \multirow[b]{2}{*}{ Mid-event } & Interview & $\begin{array}{c}\text { EWS } \\
\text { SOP/ERP }\end{array}$ & Authorities & $\begin{array}{l}\text { - Early warning } \\
\text { - Responsibilities of each authority. } \\
\end{array}$ \\
\hline & Questionnaire survey & $\begin{array}{l}\text { Actions during } \\
\text { emergency }\end{array}$ & Community & $\begin{array}{l}\text { - Do they know the evacuation route and } \\
\text { evacuation center? } \\
\text { - What should be done during an emergency? }\end{array}$ \\
\hline \multirow[t]{2}{*}{ Post-event } & \multirow[t]{2}{*}{$\begin{array}{l}\text { FGD } \\
\text { Questionnaire survey }\end{array}$} & ERP & Authorities & $\begin{array}{l}\text { - What is the plan that needs to be taken after } \\
\text { the event? } \\
\text { - Steps to improve. }\end{array}$ \\
\hline & & $\begin{array}{c}\text { Risk knowledge } \\
\text { Preparedness }\end{array}$ & $\begin{array}{l}\text { Community } \\
\text { leaders }\end{array}$ & $\begin{array}{l}\text { - How was the impact of the aftermath? } \\
\text { - Steps to be improved. }\end{array}$ \\
\hline
\end{tabular}

\section{FRAMEWORK DEVELOPMENT FOR DAM RELATED DISASTER; A CASE STUDY IN CAMERON HIGHLANDS}

The community-based organization would be responsible for the overall management of disaster reduction activities; however, this community-based organization does not have sufficient technical skills and knowledge to undertake various disaster reduction tasks. Therefore, local agencies are in a better position in facilitating and coordinating DRR plans to implement and mobilise the resources. They can provide essential technical assistance to the communities for hazard mitigation and vulnerability reduction. Participatory monitoring and evaluation should be made together between the local community and other stakeholders in measuring the progress made and identifying necessary followup actions.

In this situation, the DRR program for dam related disaster (DRD) at the downstream community of hydroelectric dam in Cameron Highlands has been conducted in 2019 (TNBR, 2020). This program is known as an Integrated Community-Based Disaster Management (ICBDM) aimed to contribute to disaster awareness and facilitate disaster management planning for a community in a vulnerable area. This people-centred program has been formulated to empower the community on how to take life-saving efforts during flood disasters occurrences induced from dam release. A non-technical based activity such as 
drill exercise and engagement program to educate local people and the school children on the importance of the dam safety preparedness has been conducted periodically among dam owners, local agencies and affected communities. The activities were planned together by dam owners, local community and local agencies as a part of participatory disaster risk management planning. Figure 4 shows the overall flows of ICBDM initiated in Cameron Highlands.

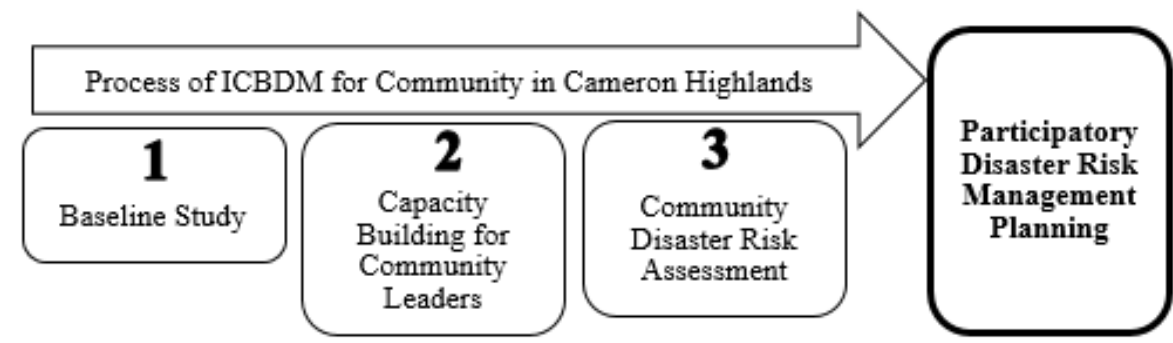

Figure 4: Steps involved in ICBDM (Adopted from Rahsidi et al., 2020)

A baseline study was conducted in Cameron Highlands to analyze the initial stage of ICBDM program. Capacity building for the community is emphasized on the role of the community leaders in the ICBDM program. Community leaders are responsible for becoming a spokesperson on behalf of the community, and at the same time as an agent to relay the message from agencies to their people (Yumagulova et al., 2019). Series of engagement programs have been conducted among dam owners, community and government agencies such as awareness workshops, dam safety seminars and exhibitions, school awareness camp and drill exercises. These programs give input and assess the effectiveness of the DRR program and emergency SOP in the study area.

The framework was outlined by emphasizing on the mode of communication, technical aspect of the dam disaster and EWS chain, and peoplecentred program. The framework corresponds to the dam owner's effort in supporting government initiatives in the United Nations program specifically for Sendai Framework (2015-2030) and Sustainable Development Goals (SDGs) aims to implement and adopt disaster risk reduction strategies at local community level. Table 2.0 lists out the basic requirements for DRD framework consists of task and responsibilities, ownership, component, and supporting resources.

Table 2.0 Main elements in DRD framework

\begin{tabular}{|l|l|c|c|}
\hline \multicolumn{3}{|c|}{ Basic requirements for DRD framework } & \multirow{2}{*}{ Supporting Resources } \\
\hline Task/Responsibility & Ownership & Component & \\
\hline
\end{tabular}


R.S. Muda, I. Tukiman, M.F.M. Amin, A.B. Khidzir

Disaster Risk Reduction Framework for Dam Related Disaster

\begin{tabular}{|c|c|c|c|}
\hline $\begin{array}{l}\text { - Hazard identification and } \\
\text { risk assessment (PE) } \\
\text { - Impact analysis (PE) } \\
\text { - Planning and strategies (PE) }\end{array}$ & $\begin{array}{c}\text { Organization \& } \\
\text { Asset } \\
\text { management }\end{array}$ & $\begin{array}{l}\text { Dam owner, local agencies } \\
\text { and authorities, policy, } \\
\text { DSERP, SOP, expertise, } \\
\text { Group of logistic, Transport } \\
\text { from responder agencies }\end{array}$ & \multirow{4}{*}{$\begin{array}{l}\text { - Human resources: expertise, } \\
\text { knowledge and technology } \\
\text { - Material; first aid, equipment } \\
\text { - Equipment; communication, } \\
\text { transportation, audio visual, etc } \\
\text { - Facilities; Warehouse, big hall, school, } \\
\text { mosque, government buildings for } \\
\text { evacuation centre, safe route } \\
\text { - Money; yearly government budget, } \\
\text { international funding, public funding, } \\
\text { private contribution, research grant, } \\
\text { institution CSR }\end{array}$} \\
\hline & Individual & Though, effort, skill and time & \\
\hline $\begin{array}{l}\text { - Active participation, } \\
\text { cooperation (PE) } \\
\text { - locally led and support (PE) } \\
\text { - } \mathrm{CIC}(\mathrm{PE})(\mathrm{ME})\end{array}$ & $\begin{array}{l}\text { Community \& } \\
\text { Local institution }\end{array}$ & $\begin{array}{l}\text { Community institutional, } \\
\text { leaders, Village program, } \\
\text { NGO, School community, } \\
\text { community institution can be } \\
\text { used for community } \\
\text { engagement }\end{array}$ & \\
\hline $\begin{array}{l}\text { - Systematically organized } \\
\text { body of knowledge (PE) } \\
\text { - Knowledge to practices } \\
\text { (PE)(ME) } \\
\text { - Medium of knowledge } \\
\text { transfer (PE)(ME)(POE) } \\
\text { - Warning chain (ME) }\end{array}$ & $\begin{array}{l}\text { Science \& } \\
\text { Technology }\end{array}$ & $\begin{array}{l}\text { EWS, Forecasting system, IT } \\
\& \text { communication, GIS, } \\
\text { mapping technology, } \\
\text { multimedia, satellite phone, } \\
\text { radio armature, signage } \\
\text { system }\end{array}$ & \\
\hline
\end{tabular}

Note: PE - Pre-Event

ME - Mid-EventPOE - Post-Event

The framework is divided into 3 phases, which are pre-event, mid-event and post event. Each phase provides systematic flow, quick response and better systems Integration in handling DRD. The framework was bound to strategize, design and prepare emergency response at the community level with consideration on the participation of multi-level stakeholders. The framework emerged a systematic methodology to minimise the impact of a disaster to the community at risk due to dam related disaster. In this case the framework is on flood induced by the dam failure. Proposed Dam related disaster Framework for emergency preparedness as shown in Figure 3.0. 


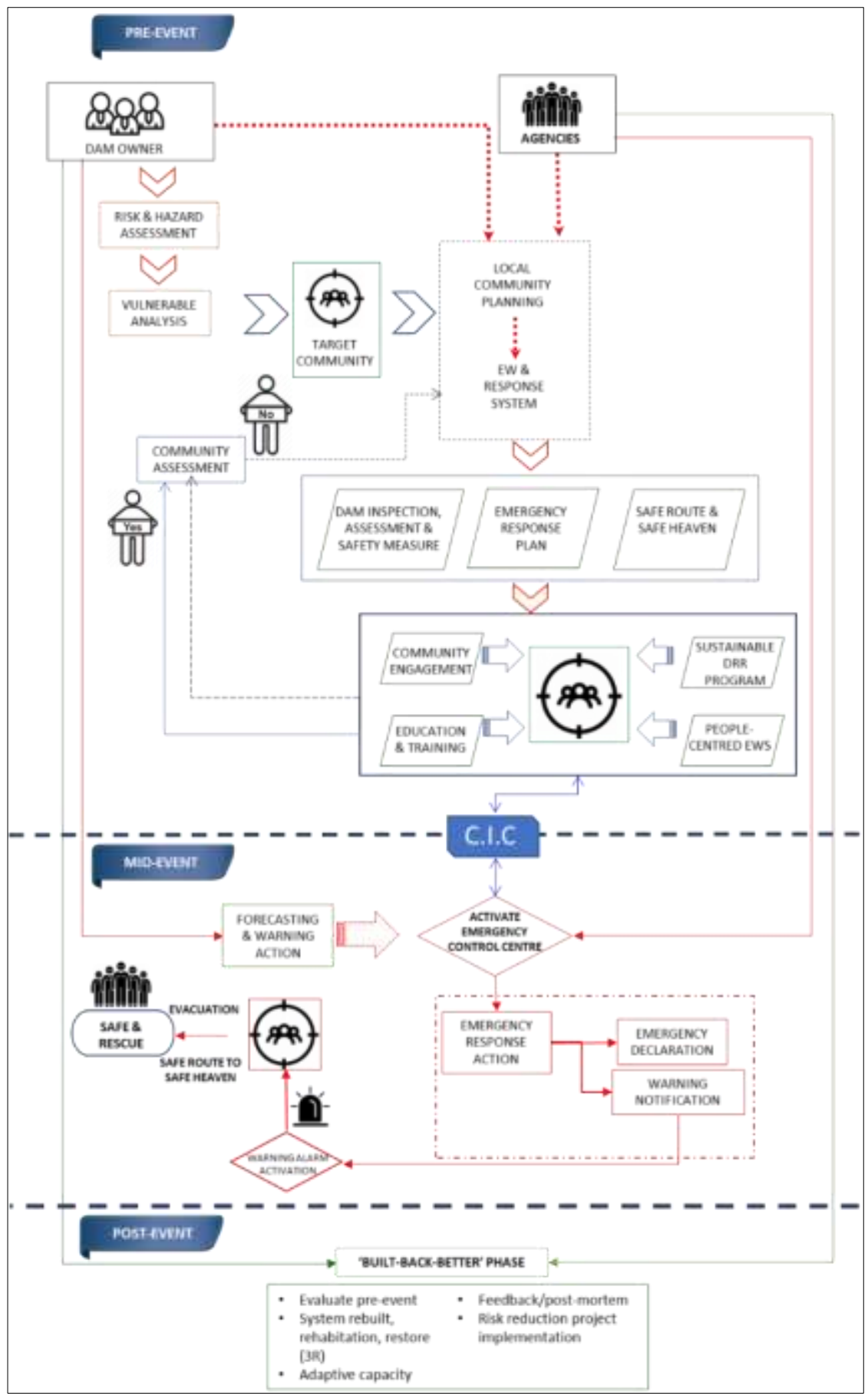

Figure 3.0: Dam related disaster Framework for emergency preparedness 
R.S. Muda, I. Tukiman, M.F.M. Amin, A.B. Khidzir

Disaster Risk Reduction Framework for Dam Related Disaster

\section{CONCLUSION}

This framework highlights the potential application of community resilience through participation and involvement of the community at the early stages of a disaster. The framework provides holistic guidance to dam owners and local agencies on the right actions to be taken during emergency situations. On the other hand, the framework outlines the systematic flow of program and action covered for all disaster phases to strengthen the preparedness of dam owner, local authorities and emergency responders involved with local communities during emergency situations. Continues assessment procedure needs to be conducted in order to sustain the effectiveness of the emergency preparedness. Therefore, it is important for dam owner to strategize a good mechanism to overcome disaster risk through its disaster management strategy. Hence, the scientific and approachable method such as EWS and other communication tools is needed to be operated effectively.

\section{REFERENCES}

Ade Bilau, A., Witt, E., \& Lill, I. (2018). Research methodology for the development of a framework for managing post-disaster housing reconstruction. Procedia Engineering, 212(2017), 598-605. https://doi.org/10.1016/j.proeng.2018.01.077

Aitsi-selmi, A., Egawa, S., Sasaki, H., Wannous, C., \& Murray, V. (2015). The Sendai Framework for Disaster Risk Reduction: Renewing the Global The Sendai Framework for Disaster Risk Reduction: Renewing the Global Commitment to People' s Resilience, Health , and Well-being. International Journal of Disaster Risk Science, 6(2), 164-176. https://doi.org/10.1007/s13753-015-0050-9

Chang-richards, A., Fredrick, K., Lindstrom, T., \& Richards, J. (2016). Measuring disaster preparedness of Auckland inner city apartment residents. January.

Eltinay, N., \& Charles, E. (2017). Disaster Risk Reduction Conceptual Framework : Open Data for Building Resilience in Critical Infrastructure . Proceeding of the 33rd Annual ARCOM Conference, September 2017.

Izumi, T., Matsuura, S., Mohd Yusof, A. F., Razak, K. A., Moriguchi, S., Kure, S., Jamal, M. H., Motoyama, E., \& Supar, L. . (2019). Disaster Risk Report:Understanding Landslides and Flood Risks for Science-Based Disaster Risk Reduction in the State of Selangor. In IRIDeS, Japan; Universiti Teknologi Malaysia (Issue 1). https://doi.org/10.11408/jierp1982.1983.4_58

Jamshed, A., Rana, I. A., Khan, M. A., Agarwal, N., Ali, A., \& Ostwal, M. (2018). Community participation framework for post-disaster resettlement and its practical application in Pakistan. Disaster Prevention and Management: An International Journal, 27(5), 604-622. https://doi.org/10.1108/DPM-05-20180161

Khalid, M. S., \& Shafiai, S. (2015). Flood Disaster Management in Malaysia: An Evaluation of the Effectiveness Flood Delivery System. International Journal of Social Science and Humanity, 5(4), 398-402. https://doi.org/10.7763/IJSSH.2015.V5.488

Maidin, S. S., Othman, M., \& Ahmad, M. N. (2017). Governance of Flood Disaster 
Framework: A Way Forward Using the Framework. Proceedings of the 6th International Conference on Computing and Informatics, 196, 650-655.

Marchezini, V., Eduardo, F., Horita, A., Matsuo, P. M., Trajber, R., Trejo-rangel, M. A., Olivato, D., \& Paul, J. D. (2018). A Review of Studies on Participatory Early Warning Systems ( P-EWS ): Pathways to Support Citizen Science Initiatives. Frontiers in Earth Science, 6(November), 1-18. https://doi.org/10.3389/feart.2018.00184

Marchezini, V., Horita, F. E. A., Matsuo, P. M., Trajber, R., Trejo-Rangel, M. A., \& Olivato, D. (2018). A Review of Studies on Participatory Early Warning Systems (P-EWS): Pathways to Support Citizen Science Initiatives. Frontiers in Earth Science, 6(November), 1-18. https://doi.org/10.3389/feart.2018.00184

Mickey Glantz, M. H., \& Ramírez, I. J. (2018). Improvisation in the time of disaster. Environment, 60(5), 4-17. https://doi.org/10.1080/00139157.2018.1495496

MKN. (2012). ARAHAN No. 20: DASAR DAN MEKANISME PENGURUSAN BENCANA NEGARA. JABATAN PERDANA MENTERI, MAJLIS KESELAMATAN NEGARA.

Mohammed, M. P. (2018). Disaster Risk Reduction and Management of Tarlac City. Procedia Engineering, 212, 77-84. https://doi.org/10.1016/j.proeng.2018.01.011

Muda, R. S., Tukiman, I., Khidzir, A. B. M., Ibrahim, A. I. N., Hussain, M. R., Rabe, N., \& Abdul Razad, A. Z. (2020). Building Capacity Through School Based Engagement on Dam Safety Program in Cameron Highlands. In Water Resources Development and Management (pp. 51-63). https://doi.org/10.1007/978-981-151971-0 6

Niekerk, D. Van. (2007). Disaster Risk Reduction, Disaster Risk Management and Disaster Management: Academic Rhetoric or Practical Reality? Journal of the Disaster Management Institute of Southern Africa, 4(1)(March), 6-9.

Okada, A. (2012). East Japan Earthquake and Tsunami: Evacuation, Communication, Education, Volunteerism. Journal of Comparative Policy Analysis: Research and Practice, 14(4), 371-372. https://doi.org/10.1080/13876988.2012.706405

Oxley, M. C. (2013). A "People-centred Principles-based" post-Hyogo framework to strengthen the resilience of nations and communities. International Journal of Disaster Risk Reduction, 4(2013), 1-9. https://doi.org/10.1016/j.ijdrr.2013.03.004

Pal, I., Ghosh, T., \& Ghosh, C. (2017). Institutional framework and administrative systems for effective disaster risk governance - Perspectives of 2013 Cyclone Phailin in India. In International Journal of Disaster Risk Reduction (Vol. 21, pp. 350-359). Elsevier. https://doi.org/10.1016/j.ijdrr.2017.01.002

Patrisina, R., Emetia, F., Sirivongpaisal, N., Suthummanon, S., Alfadhlani, A., \& Fatrias, D. (2018). Key performance indicators of disaster preparedness: A case study of a tsunami disaster. MATEC Web of Conferences, 229. https://doi.org/10.1051/matecconf/201822901010

Quansah, J. E., \& Engel, B. (2010). Early Warning Systems : A Review. The Journal of Terrestrial Observation, 2(2), 24-45.

Scolobig, A., Prior, T., Schroter, D., Jorin, J., \& Patt, A. (2015). Towards people-centred approaches for effective disaster risk management: Balancing rhetoric with reality. International Journal of Disaster Risk Reduction, 12, 202-212. https://doi.org/10.1016/j.ijdrr.2015.01.006 
R.S. Muda, I. Tukiman, M.F.M. Amin, A.B. Khidzir

Disaster Risk Reduction Framework for Dam Related Disaster

Shaw, R. (2013). Disaster Risk Reduction Approaches in Bangladesh (R. Shaw, F. Mallick, \& A. Islam (eds.)). Springer.

Shaw, R. (2014). Disaster Risk Reduction Education: Issues and Challenges (pp. 37 51). https://doi.org/10.1007/978-4-431-55090-7_3

Tiernan, A., Drennan, L., Nalau, J., Onyango, E., Morrissey, L., \& Mackey, B. (2019). A review of themes in disaster resilience literature and international practice since 2012. Policy Design and Practice, 2(1), 53-74. https://doi.org/10.1080/25741292.2018.1507240

Tipler, K., Tarrant, R., Johnston, D., \& Tuffin, K. (2017). Are you ready? Emergency preparedness in New Zealand schools. International Journal of Disaster Risk Reduction, 25(July), 324-333. https://doi.org/10.1016/j.ijdrr.2017.09.035

TNBR. (2020). Final Report: Evacuation Modelling And Development of Emergency Planning In The Event of Catastrophic Flooding From Dam Related Disasters: An Initiative for Hydroelectric Schemes Under Tenaga Nasional Berhad (TNB).

UNISDR. (2009). Terminology on Disaster Risk Reduction. International Stratergy for Disaster Reduction (ISDR), 35. https://doi.org/978-600-6937-11-3

UNISDR. (2018). Man-made and Technological Hazards; Words into Action Guidelines.

Yumagulova, L., Phibbs, S., Kenney, C. M., Yellow, D., Woman-munro, O., Christianson, A. C., \& Mcgee, T. K. (2019). The role of disaster volunteering in Indigenous communities. Environmental Hazards, O(0), 1-18. https://doi.org/10.1080/17477891.2019.1657791

Received: $15^{\text {th }}$ May 2020. Accepted: $1^{\text {st }}$ Sept 2020 